\title{
The architecture of national boundary regimes: mapping immigration and citizenship policies in 23 democracies 1980-2010
}

\author{
Samuel D. Schmid ${ }^{1,2}$ (D)
}

Correspondence: schmid@mmg. mpg.de

${ }^{1}$ Max Planck Institute for the Study of Religious and Ethnic Diversity, Göttingen, Germany

${ }^{2}$ European University Institute, Florence, Italy

\begin{abstract}
In this article, I introduce a typology that maps the regulation of two fundamental boundaries of modern nation-states regarding immigration: territorial boundaries and membership boundaries. Based on a theory of the structural logics underlying Immigration Regime Openness (IRO) and Citizenship Regime Inclusiveness (CRI), I make four observations on the two-dimensional policy space determined by the relative porousness of these two boundaries. First, a Categorical Principal Component Analysis (CATPCA) using a combination of original and existing panel data across 23 liberal democracies from 1980 to 2010 confirms that IRO and CRI are internally consistent and statistically distinct dimensions. Immigration policies therefore appear more coherent than often assumed. Second, the distribution of cases over the four ideal-typical policy configurations from 1980 to 2010 shows that more and more cases combine relatively liberal immigration policies with relatively liberal citizenship policies. Behind this finding are, third, overall liberalizing trajectories in both policies as well as a pattern of convergence in immigration policies. The liberalisation of immigration policies is most notable until 1996 and the level of openness fluctuates thereafter. Regarding citizenship, I provide evidence for a much-cited restrictive turn during the 2000s. In addition, I show that there has already been a restrictive turn in citizenship during the 1990s. Fourth, instead of the trade-off anticipated by much of the literature, I find an increasingly positive correlation between IRO and CRI. The new typology, its underlying theory, and the subsequent findings significantly advance our understanding of the most fundamental boundaries of modern nation-states.
\end{abstract}

Keywords: Immigration policies, Citizenship policies, Typology, Principal component analysis, Policy trends

\section{Introduction}

Immigration-related policies can be conceptualised along two basic dimensions. On the one hand, territorial boundaries are about immigration policy and refer to territorial admission and the granting of (long-term) legal residence. On the other hand, membership boundaries are about immigrant policy and refer to the treatment of

(c) The Author(s). 2020 Open Access This article is licensed under a Creative Commons Attribution 4.0 International License, which permits use, sharing, adaptation, distribution and reproduction in any medium or format, as long as you give appropriate credit to the original author(s) and the source, provide a link to the Creative Commons licence, and indicate if changes were made. The images or other third party material in this article are included in the article's Creative Commons licence, unless indicated otherwise in a credit line to the material. If material is not included in the article's Creative Commons licence and your intended use is not permitted by statutory regulation or exceeds the permitted use, you will need to obtain permission directly from the copyright holder. To view a copy of this licence, visit http://creativecommons.org/licenses/by/4.0/. 
immigrants after the establishment of (long-term) residence. Hammar (1985), who popularised this distinction, further differentiates two kinds of immigrant policies. The first concerns the rights afforded to 'denizens' (Hammar 1990), while the second concerns citizenship policies - that is, the regulation of the access to citizenship in the sense of passport-holding or nationality.

The aim of this article is to theorize, explicate, and assess this two-dimensional architecture of national boundary regimes and explore its evolution over time. I zoom in on immigration regimes and citizenship regimes to address three intertwined questions:

(1) What are the main structural logics shaping immigration regimes and citizenship regimes in liberal democracies?

(2) Do these two policy dimensions and the resulting two-dimensional policy space follow from these structural logics, and does this two-dimensional model withstand empirical testing?

(3) What do the structural logics tell us about the trends in, the configurations of, and the correlations between immigration regimes and citizenship regimes across space and time, and can these theoretical expectations be empirically corroborated?

To answer these questions, I draw on the account of Hampshire (2013) to argue that immigration policies and citizenship policies are driven by the divergent logics of markets and nations, as well as the intermediate logics of overarching liberal-constitutional and democratic institutions. Immigration policies are mainly exposed to economic and legal forces, while citizenship policies are primarily driven by democratic concerns and national identities. This structural divergence gives rise to the distinct empirical nature of immigration regimes on the one hand and citizenship regimes on the other.

I further propose that each structural logic can come in a liberal or open or inclusive, or an illiberal or closed or exclusive variant. It should thus be possible to observe all four logical combinations of open or closed immigration policies and inclusive or exclusive citizenship policies. Moreover, in line with much of the existing literature that discusses this problem under the heading of the 'gap hypothesis' (e.g. Cornelius et al. 2014; Lutz 2019), I argue that external constraints imposed by global markets and international institutions favour open and liberal policies in the realm of immigration, while citizenship policies are less externally constrained and thus more malleable by domestic structures and political forces. This should set immigration policies on a more liberalising and convergent trajectory than citizenship policies. I then suggest that the structural logics underpinning each dimension pulls immigration regimes and citizenship regimes apart. Hence, they should not only be conceptually and statistically distinct, but also not systematically correlated.

Using Categorical Principal Component Analysis (CATPCA) to scrutinize data across 23 liberal democracies from 1980 to 2010, the empirical investigation validates The National Boundary Regime Typology. The policy components of Immigration Regime Openness (IRO) and Citizenship Regime Inclusiveness (CRI) can be reduced to two internally consistent and statistically distinct dimensions. By demonstrating the empirical existence of theoretically assumed dimensions, this analysis thus addresses an important gap in the literature (Koopmans 2013: 696). There are studies that have introduced two-dimensional policy spaces of integration and citizenship regimes without testing 
this dimensional assumption (Koopmans et al. 2005; Goodman 2010), while others who analysed citizenship regimes more comprehensively (by adding, among other things, indicators on the loss of citizenship) validated their two-dimensional model (Vink and Bauböck 2013). Inspired by recent literature (Boucher and Gest 2015), this study is the first to combine immigration policies and citizenship policies with a novel twodimensional scheme capturing regimes proper (i.e. policies as such).

Based on the typology, I then show that over the observed time period, an increasing number of cases can be described as open-inclusive boundary regimes: they have relatively open borders and relatively inclusive citizenship. In fact, open-inclusive regimes are the most common in the sample. However, many cases still show other configurations. One notable finding regarding these other types is that closed-inclusive regimes are the least frequent, even though they embody the conventional liberal-communitarian model defended in classical normative accounts in democratic theory (e.g. Walzer 1983, ch. 2).

Furthermore, the analysis shows that the aggregate levels of both IRO and CRI follow overall liberalising trajectories. However, after a surge in liberalisation from 1980 onwards, immigration policies start fluctuating after 1996. Citizenship policies show a much-observed restrictive turn during the 2000s. I also show that there has already been a restrictive turn in citizenship during the 1990s. Finally, I find that immigration regimes show increasingly similar levels of openness while citizenship regimes do not converge significantly overall.

The liberalising tendencies in both immigration policies and citizenship policies contrast with the finding of a proliferating 'Market Model' (Boucher and Gest 2018), which occupies a middle ground between the closed-exclusive and open-exclusive types of boundary regimes. The sample and type of indicators used in this article show that, instead, the 'Liberal Model' (ibid.) of open-inclusive regimes is more prevalent. Furthermore, these results cast doubt on the notion that democracies remain trapped in 'liberal paradox' that manifests itself in a tension between open borders and inclusive citizenship (Hollifield 1992, 2004). Rather, this 'paradox' is increasingly resolved. Meanwhile, the finding of substantial convergence in immigration regimes but not citizenship regimes is more in line with the existing literature (e.g. Helbling and Kalkum 2018; Koopmans et al. 2012).

The last part of the article uses the two-dimensional policy space to analyse the correlation between immigration regimes and citizenship regimes. Calculating the pooled correlation for three time periods (last decade of the Cold War: 1980-1991; 19922001; and post 9/11), I show that the two dimensions are in fact not uncorrelated; the correlation has become increasingly positive. Challenging widespread notions of tradeoffs between openness and inclusiveness (e.g. Ruhs 2013), this finding suggests a more intricate interplay and potential convergence of the structural logics behind the two policies realms across time.

\section{Defining national boundary regimes regarding immigration}

National boundary regimes regarding immigration are constituted by two sets of policies: immigration regimes and citizenship regimes. Immigration regimes are, on the one hand, constituted by the legal regulations that define the conditions for and guide 
the volume of immigrant intake to a receiving country (Goodman 2014a, p. 814; Helbling et al. 2017, p. 82). These policies distinguish different types of immigrants, namely labour immigrants, immigrants that reunite with their families, and asylum seekers and refugees (Helbling et al. 2017). Examples are conditions such as job offer requirements for labour migrants or eligibility criteria such as age limits for family migrants.

On the other hand, immigration regimes confer residence rights. These rights define how long an immigrant can stay in the receiving country under the relevant permit. This is not to be confused with the regulation of permanent residence proper, which may or may not depend on additional conditions. For instance, Green Card holders in the US receive permanent residence rights upon admission, whereas in other countries residence rights may not allow any category of migrants to renew their temporary visas or transition toward a permanent stay.

Conceptualizing residence rights as a part of immigration regimes does not conflate immigration policy with immigrant policy. Non-transient residence rights short of the regulation of access to permanent residence proper are immigration rights, not immigrant rights. Indeed, regulating the duration of stay is a necessary component of any immigration policy; it is associated directly with entry permits. Depending on the number of possible permits and their variation in legal content, such permit rights do not only exhibit cross-national but also intra-national variation across entry tracks (cf. Ruhs 2013).

By contrast, more general rights mainly show cross-national rather than intra-national variation (cf. Koopmans et al. 2012). General rights may still discriminate between various categories of migrants, but not based on permits. It is hard to give examples for rights in the two categories because the distinction is somewhat artificial, and the rights architecture can vary across countries - a fact that is usually not acknowledged and is hard to capture empirically. A safe bet for a general right is the right of non-citizens to vote in local elections. Here, states discriminate on grounds of nationality and duration of residence rather than residence permits (Schmid et al. 2019).

Permit rights, and especially residence rights, constitute the inner belt of the territorial boundary instead of an intermediate stage between entry and naturalisation (Helbling et al. 2017; see also de Haas et al. 2015). Hence, immigration regimes, as conceptualised here, feature entry and stay as their constituent components. The less restrictive the regulations of entry and stay, the higher the level of Immigration Regime Openness (IRO).

Regarding immigration, citizenship regimes comprise the regulations that define the conditions for immigrants to acquire the legal status of full membership in the sense of nationality (Goodman 2014a, 814). Based on a review of extant indices and other conceptualisations in the literature (e.g. Howard 2009; Fitzgerald et al. 2014; Blatter et al. 2017), this analysis focuses on four core policy components of citizenship regimes: (1) the strength of jus soli; (2) residence duration requirements; (3) the toleration of multiple citizenship; and (4) further naturalisation requirements (language and citizenship tests as well as economic and criminal record requirements). The less restrictive the requirements for citizenship acquisition for immigrants, the higher the level of Citizenship Regime Inclusiveness (CRI).

The overarching concept of national boundary regimes regarding immigration therefore focuses the two fundamental 'social closures of nation-states' (Brubaker 1992, ch. 1 ; Weber 1946, p. 78). The inner boundary of citizenship is fundamental because it endows immigrants with the 'highest standard of equal treatment' (Bauböck et al. 2013, p. 
40). If access to citizenship were completely blocked, immigrants could never become equals. In addition, the transformation of non-citizens into citizens has crucial repercussions on territorial admission: It permanently unlocks access to a state's territory by establishing the right of unconditional re-entry and residence. The outer boundary of immigration is also fundamental. If it were completely blocked, citizenship could never be reached. Indeed, the territorial boundary is 'citizenship's perpetual gatekeeper' (Joppke 2010, p. 150).

Immigrant rights are important, but not as fundamental as immigration policies and citizenship policies. Still, one may argue that the architecture of national boundary regimes cannot be properly conceptualised and understood without the dimension of immigrant rights. However, there are empirical, theoretical, and pragmatic reasons to omit this dimension. First, Huddleston and Vink (2015) provide empirical evidence showing that various general rights and the ease of access to citizenship are so highly correlated that they can be reduced to the same empirical dimension. They identify the citizenship policy component as the 'best predictor' of the overall rights regime. Second, granting rights amounts to boundary blurring between citizens and non-citizen residents, while the establishment of long-term legal residence upon immigration and the inclusion into a receiving country's national community regulate the more fundamental aspect of boundary crossing. Lastly, comprehensive data on immigrant rights for the sample and timeframe used in this study are not available, especially for the last decades of the old millennium. Such data would be very laborious to collect, especially when one considers a wide variety of rights. To make such an endeavour possible we would also have to narrow the number of rights we examine, provoking the need for a selection that can be widely agreed upon. For these reasons, I leave aside immigrant rights and focus instead on the fundamental boundaries defined by IRO and CRI.

\section{Theorizing the architecture of national boundary regimes}

To theorize the architecture of national boundary regimes, I first take a step back and examine the idea of the liberal paradox. Coined and elaborated by Hollifield (1992, 2004), it refers to the tension between economic liberalism and political liberalism in regulating immigration and the access to citizenship. To maximize material welfare in a globalizing world, transnational economic forces propel liberal states toward greater openness in territorial admission (Hollifield 2004, p. 902). At the same time, however, to ensure security, to preserve the democratic social contract, and to protect the cultural cohesion of the national community, political forces push for greater territorial closure (ibid.). Furthermore, however, whereas economic liberalism tends to see foreign workers as commodities, the liberal constitutional order of democracies provides the grounds for granting them rights and citizenship (Hollifield 1992).

Against this background, Hollifield points to two possible outcomes. The first is that - in the context of a growing international labour market - an individualist understanding of political liberalism points to the possibility of a "gradual resolution of the liberal paradox" (Hollifield 1992, p. 223). Indeed, for Hollifield, "rights-based liberalism goes hand-in-hand with the spread of market relations", and it is this "confluence of unregulated markets for foreign labour and the rise of rights-based politics that explains the failure of restrictionist policies and the persistence of immigration" (ibid., p. 
170). The second possibility - stated as a conclusion in various pieces (e.g. Hollifield 2004, 905; Hollifield and Faruk 2017, 143) - is that "[e]ven as states become more dependent on trade and migration, they are likely to remain trapped in a liberal paradox for decades to come."

These two possibilities still feature in the current scholarly discourse. However, where Hollifield has envisioned a gradual resolution to the liberal paradox towards a comprehensively liberal model reconciling open borders and inclusive citizenship in the long run, others have suggested that more and more states show a seemingly 'paradoxical' configuration of open borders and exclusive citizenship. For instance, Boucher and Gest (2018) contrast the 'Liberal Model' with the 'Market Model'. The latter embodies the tension between the openness towards certain (mostly temporary and high-skilled) labour migrants and the closure towards others, as well as patterns of citizenship exclusiveness. However, rather than 'being trapped' in this tension, governments may embrace it because it allows them "to have it both ways - effectively sanitizing globalisation from its purported ills while enjoying the benefits it brings" (ibid., p. 6).

In the following, I suggest that not only two but four national boundary regime types should be theoretically possible and empirically observable. This is based on a theory of structural logics and their interaction in shaping coherent immigration regimes and coherent citizenship regimes, respectively. The resulting two-dimensional policy space and its four ideal-typical configurations follow from these structural logics.

My starting point is the account of Hampshire (2013). He argues that there are four potentially 'contradictory imperatives of the liberal state' (ibid., p. 2). These are: capitalism, constitutionalism, representative democracy, and nationhood. Hampshire then goes on to argue that the former two tend to induce openness, while the latter two tend to generate closure. However, he also extends this structural account with a complex and comprehensive framework of how factors such as politicisation, public opinion, or labour market conditions, and actors such as far-right parties, courts, or firms may affect immigrationrelated policy-making in these four facets of the liberal state (ibid., p. 51-4).

My modified version of Hampshire's framework mirrors these liberal imperatives by focusing on the following structural logics: the economic logic of the market, the legal logic of the liberal state, the democratic logic of the liberal state, and the cultural logic of the nation. I shall argue that the former two are complementary in shaping immigration regimes, while the latter two are complementary in shaping citizenship regimes. Furthermore, I suggest that each structural logic comes in two variants, liberal or illiberal, open or closed, and inclusive or exclusive.

The economic logic of the market is where, first and foremost, labour immigration policies can be located. They are embedded in the dynamics and the regulation of transnational trade and shaped by the behaviour and lobbying activity of labourintensive firms (Peters 2017). Because of their commitment to economic liberalism in the context of globalisation, democracies tend to allow certain interest groups - namely firms - to capture command in steering labour immigration. In the modern dual labour market, low-skilled and high-skilled immigration policies can thus expand simultaneously. This dynamic of 'client politics' is likely to emerge despite popular opposition because the costs of immigration for the broader and disorganised public are diffused, while the benefits are highly concentrated in well-organised business coalitions (Freeman 1995). Thus, the inherent tendency in the economic logic of the market 
regarding immigration policies is one of expansive openness. However, we can imagine a situation in which national labour markets start following a closed protectionist logic. Peters (2017) shows, for instance, that in reaction to greater openness to trade, firms move their production abroad, taking their jobs with them. Such firms then demand more closed immigration policies at home as the need for migrant labour decreases.

The legal logic of the liberal state manifests in "legal-constitutional constraints on the executive" (Joppke 1998) by independent judiciaries on both the international and the national level. Because of these constraints, in liberal democracies rights to family reunification cannot be significantly curbed and may acquire an expansive dynamic (Joppke 1998, 2001; see also Hollifield 1992, p. 94). A case in point is the liberalisation of family reunification after officially terminating temporary guest worker schemes in countries like Germany after the oil crisis in the 1970s. Rather than (re-)uniting in their countries of origin, the families of migrant workers did so in the countries of destination. Courts intervened, and executive and administrative authorities had to follow suit (Hollifield 2004, p. 895).

Policies targeting asylum seekers and refugees also find grounding in liberal norms. Some of these norms, namely the principle of non-refoulment, operate at the international level (Neumayer 2005, pp. 56-7). Independent judiciaries in democratic nation-states often further facilitate the access of those with claims to asylum and refugee status. As with family reunification, in this realm courts again appear as the phalanx of political liberalism. However, asylum and family reunification have become increasingly politicised over time. Thus, an illiberal variant of the legal logic seems possible when certain political players are in power, and especially when strong illiberal political forces hijack the liberal state and the independent nature of the judiciary (which is not so hard to imagine in the current populist era).

Thus understood, economic liberalism and political liberalism can be interpreted as two parallel threads knit into the same fabric of liberal democracies. They are friends, not enemies. Rather, their common enemy is closed and exclusive illiberalism. One implication of this proposition is that immigration policies in all their aspects - labour migration, family reunification and asylum and humanitarian protection - should be positively correlated to a high degree; they should be reducible to a single consistent dimension of IRO. In addition, for democracies the liberal mode can be assumed to be the natural mode; some illiberal element or actor must be added to derail this inherent liberal tendency. This liberal logic underpinning immigration policies is further amplified by strong economic and political constraints imposed by globalised (labour) markets and liberal international institutions (cf. Sassen 1996). These factors lead to a 'liberal bias' in immigration policies - a gap between the restrictionist bent of public opinion and liberal immigration policy-making (Cornelius et al. 2014; Lutz 2019). Thus, contrary to what many believe to be an age of restrictionism, we can expect that immigration regimes should exhibit an overall liberalising trajectory over recent decades.

To theorize citizenship regimes, I go back to Hollifield's usage of the term political liberalism. It combines rights-based liberalism with the collective right of (native) democratic communities to national self-determination. This conception of political liberalism is, therefore, intimately connected to concepts of nationhood and citizenship. Against this background, I suggest that citizenship regimes are, first and foremost, 
underpinned by a cultural logic of the nation. Citizenship policies with an inclusive tendency are based on inclusive conceptions of national identity (cf. Brubaker 1992). Emphasizing the individual right of immigrants to inclusion, the key purpose of such an inclusive citizenship regime is to ensure democratic legitimacy vis-à-vis migrant newcomers as they are subjected to the rule of the receiving state. Inclusive national identities are thus wedded to a democratic logic of the liberal state.

By contrast, citizenship policies that tend towards the exclusionary pole are rooted in exclusive conceptions of national identity (cf. Brubaker 1992). They subsume the egalitarian logic of the liberal state under a collectivist logic of the nation and the rights to selfdetermination and the idea of boundedness of the native majority. Emphasizing the right to exclusion, the key concern here is democratic legitimacy vis-à-vis native citizens as they strive to preserve socio-cultural cohesion and the cultural distinctiveness of their national identity. Hence, exclusive national identities are wedded to an illiberal democratic logic.

The modus vivendi of liberal states can be located in a comprehensively democratic logic. This should lead to a tendency of greater inclusiveness in citizenship over time. However, this tendency is weak because citizenship regimes regarding long-term immigrants are not subject to forces of globalisation and liberal biases as much as immigration regimes are (Lutz 2019). ${ }^{1}$ Instead, marking the last, though perhaps falling, "bastion of sovereignty" (Dauvergne 2004; Spiro 2011), citizenship policies can be expected remain on trajectories that continue to significantly vary across states (cf. Koopmans et al. 2012). Table 1 provides an overview of these arguments.

In sum, on the one hand, citizenship regimes can be conceived as being mainly exposed to slow-moving logics of culture and national identity as well as the medium-paced logic of democracy. Thus understood, citizenship regimes are a product of the interaction of the cultural logic of the nation with the democratic logic of the liberal state. Immigration policies, on the other hand, are mainly driven by fast-moving economic forces as well as medium-paced legal and political dynamics. They are a product of the interaction of the economic logic of the market with the legal logic of the liberal state.

This brings me to my last proposition. Since the two policy areas of immigration and citizenship tap into different societal domains and are driven by distinct structural logics, IRO and CRI should not only be conceptually and statistically distinct, but also statistically independent - that is, they should not be systematically correlated. This hypothesis stands in contrast to the common assumption that there is a trade-off between the openness of borders and the inclusiveness of citizenship (e.g. Ruhs 2013).

\section{The National Boundary Regime Typology}

If immigration regimes and citizenship regimes are distinct and internally coherent, the resulting policy space should feature four ideal-typical configurations. Bosniak (2006, p. 119) explains that the "hard-on-the-outside, soft-on-the-inside model [ ...] is the prevailing and commonsense normative account." This is the broad agreement that the relatively hard shell or highly erected gate (restricted immigration) of democratic nation-states makes possible and protects the soft inside (inclusive citizenship). The

\footnotetext{
${ }^{1}$ There has also been a marketisation of citizenship. For instance, certain states have introduced citizenshipfor-sale schemes to attract 'high value migrants' and investments (Shachar 2018; Džankić 2019). However, this has happened at the margins of citizenship regimes as they are defined here. They do not concern ordinary immigrants.
} 
Table 1 Overview of the analytical framework and its empirical implications

\begin{tabular}{|c|c|c|c|c|c|c|c|}
\hline \multirow[t]{2}{*}{ Logic } & \multirow[t]{2}{*}{ Variants } & & \multicolumn{2}{|l|}{ Relevance } & \multirow{2}{*}{$\begin{array}{l}\text { Globalisation } \\
\text { Constraints }\end{array}$} & \multicolumn{2}{|l|}{ Tendency } \\
\hline & & & $\begin{array}{l}\text { Immigration } \\
\text { Regime }\end{array}$ & $\begin{array}{l}\text { Citizenship } \\
\text { Regime }\end{array}$ & & $\begin{array}{l}\text { Immigration } \\
\text { Regime }\end{array}$ & $\begin{array}{l}\text { Citizenship } \\
\text { Regime }\end{array}$ \\
\hline \multirow{2}{*}{$\begin{array}{l}\text { Economic } \\
\text { logic of the } \\
\text { market }\end{array}$} & Open & $\begin{array}{l}\text { Transnational } \\
\text { labour markets }\end{array}$ & \multirow[t]{4}{*}{ High } & \multirow[t]{4}{*}{ Low } & \multirow[t]{4}{*}{ High } & $\begin{array}{l}\text { Strong liberal } \\
\text { tendency }\end{array}$ & \\
\hline & Closed & $\begin{array}{l}\text { Protectionist } \\
\text { national labour } \\
\text { markets }\end{array}$ & & & & & \\
\hline \multirow[t]{2}{*}{$\begin{array}{l}\text { Legal logic } \\
\text { of the liberal } \\
\text { state }\end{array}$} & Liberal & $\begin{array}{l}\text { Independent } \\
\text { and strong judicial } \\
\text { review }\end{array}$ & & & & & \\
\hline & |lliberal & $\begin{array}{l}\text { Non-independent } \\
\text { and weak judicial } \\
\text { review }\end{array}$ & & & & & \\
\hline \multirow[t]{2}{*}{$\begin{array}{l}\text { Democratic } \\
\text { logic of the } \\
\text { liberal state }\end{array}$} & Liberal & $\begin{array}{l}\text { Democratic rights } \\
\text { extended to } \\
\text { immigrants }\end{array}$ & \multirow[t]{4}{*}{ Low } & \multirow[t]{4}{*}{ High } & \multirow[t]{4}{*}{ Low } & & \multirow[t]{4}{*}{$\begin{array}{l}\text { Weak liberal } \\
\text { tendency } \\
\text { Non-convergent }\end{array}$} \\
\hline & Illiberal & $\begin{array}{l}\text { Democratic rights } \\
\text { reserved for natives }\end{array}$ & & & & & \\
\hline \multirow{2}{*}{$\begin{array}{l}\text { Cultural } \\
\text { logic of the } \\
\text { nation }\end{array}$} & Inclusive & $\begin{array}{l}\text { Inclusive national } \\
\text { identities }\end{array}$ & & & & & \\
\hline & Exclusive & $\begin{array}{l}\text { Exclusive national } \\
\text { identities }\end{array}$ & & & & & \\
\hline
\end{tabular}

normative model that corresponds most closely to this regime is liberal communitarianism (the classic statement is Walzer 1983, ch. 2) and can be abbreviated as closedinclusive.

The diametrically opposing normative ideal-type is neo-liberal utilitarianism (see e.g. Ruhs 2013): Immigration is liberalised, but citizenship is exclusive; it is open-exclusive. By emphasizing economic openness to harness the benefits of globalisation, while at the same time controlling its impact on the fabric of the national political community by keeping or making citizenship exclusive, the neo-liberal regime type resembles the notion of the liberal paradox (Hollifield 2004).

The typology is completed by liberal cosmopolitanism and its counterpart illiberal nativism. The former combines open labour markets with rights to family reunification and the right to humanitarian protection and asylum as well as inclusive citizenship (see e.g. Carens 2013). This open-inclusive policy configuration thus embodies the resolution of the liberal paradox and has been abbreviated as the 'Liberal Model' (Boucher and Gest 2018). Illiberal nativism has relatively closed borders, and its citizenship is relatively exclusive; it is closed-exclusive. The 'Market Model' (Boucher and Gest 2018) is selectively open but exclusive and thus can be located in between the illiberal and the neo-liberal model. Figure 1 summarises this typology.

If IRO and CRI indeed increase over time, we can expect that more and more cases should be open-inclusive. However, if the liberalising and convergent tendency is indeed stronger for immigration regimes, the continued non-convergence in CRI should also lead to a substantial number of open-exclusive cases.

\section{Data and methods}

To measure the various components of Immigration Regime Openness (IRO), this article uses data of the Immigration Policies in Comparison project (IMPIC; Helbling 


\section{The National Boundary Regime Typology}
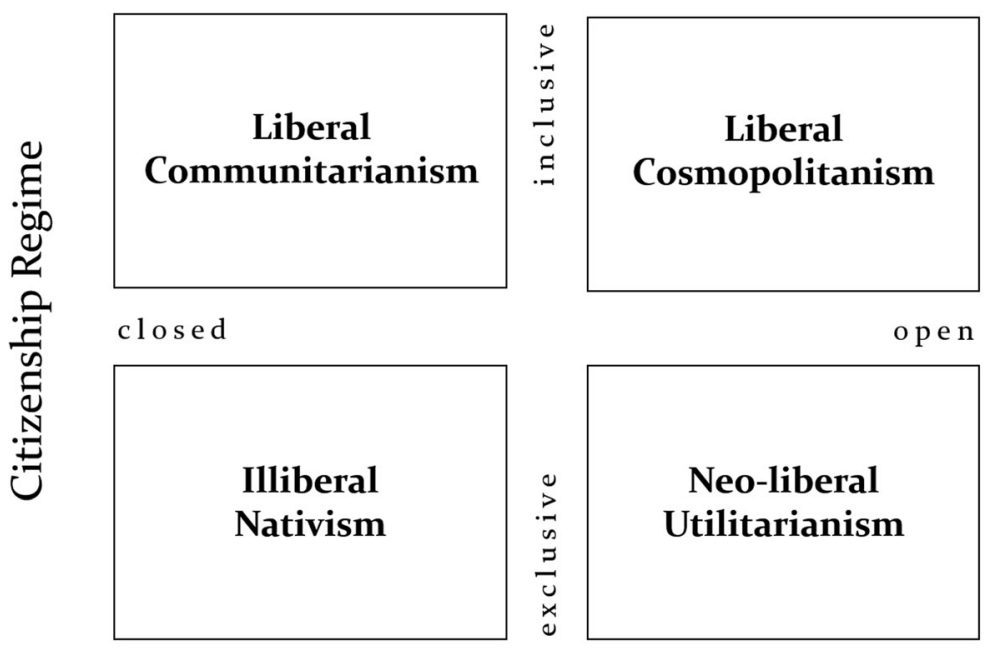

\section{Immigration Regime}

Fig. 1 The National Boundary Regime Typology

et al. 2017). IMPIC covers 33 OECD countries from 1980 to 2010 (unfortunately, at this point, no data is available after 2010 and it is too resource-intensive for an individual researcher to update it). To measure Citizenship Regime Inclusiveness (CRI), I have created an original dataset that builds on the most essential elements that can be found in the Migration and Integration Policy Index (MIPEX) strand on Access to Nationality (Huddleston and Niessen 2011). In addition, I have relied on data from Stadlmair (2017), Fitzgerald et al. (2014), de Haas et al. (2015) as well as those provided by the Global Citizenship Observatory (GLOBALCIT). ${ }^{2}$ Called Citizenship Regime Inclusiveness Index (CITRIX), the dataset therefore does not reinvent but rather reassemble the citizenship wheel. I only provide a short description of CITRIX here, while more details and validity tests can be found in Additional file 1.

Attempting to find a balance between high spatio-temporal coverage and sufficient unit homogeneity, the case selection criteria are as follows. For pragmatic reasons, a country must be covered by both IMPIC and CITRIX. In terms of substance, a country must have been an independent and liberal-democratic state, whose adherence to rule of law and whose effective state apparatus mean that policy outputs are implemented. Even though such states do not necessarily have a net migration rate that is tilted towards immigration rather than emigration over the whole period, one can assume that all of them are attractive for migrants as countries of destination. IMPIC and CITRIX overlap for 23 OECD countries from 1980 to 2010 (though CITRIX is also available until 2014). These countries also fulfil the substantive case selection criteria. They include the EU member states forming the EU-15, Norway, Switzerland, Iceland, and Japan, as well as the classical

${ }^{2}$ www.globalcit.eu 
Western settler states - the United States, Canada, Australia, and New Zealand. This leads to 713 country-year observations.

Part of the analysis will sub-divide the timespan from 1980 to 2010 into three geopolitical periods to detect changes over time. They roughly correspond to the three decades. The 1980-1991 period marks the final years of the Cold War. After the collapse of the Soviet Union, the world has become fundamentally different. Globalisation picked up speed and the USA sat at the top of the liberal world order during the 19922001 period. The world changed again in fundamental ways after 9/11. Especially the latter event is often assumed to be important for (changing) immigration and citizenship policies.

In line with the concept specification outlined in the first part of this article, the measurement of IRO covers the policy fields of labour immigration, family reunification, and asylum. There are two components for each field: entry and stay. Entry requirements define the criteria that immigrants need to fulfil to be able to enter a host country (called eligibility and conditions in IMPIC). Conditions for stay define the security of status and the possibilities for long-term settlement associated with a specific entry permit (called security of status in IMPIC; for details see Bjerre et al. 2016). This leads to a total of six policy components.

Based on the conceptualisation of CRI above, CITRIX is composed of four policy components. These are (1) the strength of jus soli; (2) residence duration requirements; (3) the toleration of multiple citizenship; and (4) further naturalisation requirements, namely language tests and citizenship tests as well as economic and criminal record requirements. The first is measured as years and then rescaled from 0 to 100 with 100 indicating the least amount of years required in the sample. For the others the threepoint 0-50-100 MIPEX scales are applied, though for one jus soli indicator the scale is refined and for the dual citizenship component it is rearranged. More details as well as validity tests of CITRIX can be found in Additional file 1. In Additional file 1, I also offer some reflections on building indices of immigration policies, elaborating on how the country-year methodology used to measure immigration regimes qualifies the analysis, and how it compares to other approaches in the literature.

The IMPIC components are coded with an ordinal restrictiveness scale from 0 to 1 , using theoretical minima and maxima (Helbling et al. 2017, p. 89). A score of 1 indicates maximum restrictiveness. I reverse the scales and linearly transform them so that 0 represents the empirical minimum and 100 the empirical maximum. Except for the residence duration requirement, the data of CITRIX are also ordinal. Also, there 0 represents the empirical minimum and 100 the empirical maximum. Given the ordinal scaling, I use categorical instead of standard principal component analysis (CATPCA; Meulman and Heiser 2005) to analyse the dimensionality of the data. This method can accommodate variables that are scaled at various levels (residence duration is deemed numeric) with the aim of modelling non-linear relationships. The output of CATPCA is similar to standard PCA - it can be interpreted in the same way (Linting et al. 2007, pp. 27-8).

For the empirical analysis, the 713 country-year observations are pooled. This means that each indicator in each country and year is correlated with the indicator in that country in the previous year. Whether this autocorrelation poses a problem for principal component analysis has been contested. Jolliffe (2002, p. 299) argues that this problem poses no serious threat if the main goal of PCA is descriptive. This applies to my 
analysis. In addition, this pooled approach has already been used to construct immigration policy openness indices by applying standard PCA analysis to ordinal data (e.g. Peters 2017).

The CATPCA is confirmatory rather than exploratory. Hence, rather than relying on extraction criteria such as component Eigenvalues greater than 1 - a criterion often used for exploratory principal component analyses - a solution with two dimensions is specified ex ante. The CATPCA therefore tests whether the various policy components can indeed be reduced to two distinct and internally consistent dimensions that describe IRO and CRI, respectively. Additional tests with more and fewer dimensions are provided in Additional file 1. The tests show that the two-dimensional model is the most adequate.

For the subsequent analyses, I do not use the component scores from the CATPCA. This is not only because they are highly skewed, but also because the rotation used (VARIMAX; see below) assumes statistical independence, thus making correlation analyses futile. Instead, I use equally weighted average scores based on the six IRO policy components and the four CRI policy components, respectively. As the IRO values are still highly skewed, however, I apply a cubic transformation to better identify the important sources of variation. More details and justifications for this decision are elaborated in Additional file 1.

For the configurational analysis, the typology is used as a heuristic tool to make simplified nominal regime classifications. Both theoretically and empirically there are no clear thresholds above which cases are open or inclusive in an absolute sense. At least when conceptualised and measured in a statistical rather than a set-theoretic the openness of borders and the inclusiveness of citizenship are matters of degree, not of kind (cf. Vink 2017, p. 226). However, I still categorise cases as instances of the four regime types, but only in a relative way by using the arithmetic means of IRO and CRI as the cut-off points.

\section{Dimensional analysis}

Do the components of IRO and CRI configure along two internally consistent and statistically distinct dimensions? A confirmatory CATPCA reveals that a two-dimensional model indeed provides an adequate description of the data. Both dimensions are relevant in terms of their Eigenvalue, and the model explains almost $60 \%$ of the variation in all items (Table 2; a correlation matrix of all variables can be found in Additional file 1). The first dimension describes Immigration Regime Openness (IRO), the second Citizenship Regime Inclusiveness (CRI). While the dimension describing CRI is not fully consistent as the Cronbach's alpha score is below the standard threshold for internal consistency of 0.7 , the model performs well. This indicated by the high value of the Cronbach's alpha assessing the full model.

This finding adds to the existing literature in several ways. First, previous studies have cautioned against the idea that there is a general tendency in immigration policies across its various dimensions in terms of degrees of restrictiveness (Beine et al. 2016; de Haas et al. 2016). The analysis presented here instead suggests that immigration regimes are rather coherent. It corroborates the idea that IRO - in terms of entry and stay policies regarding labour immigration, family reunification, and asylum seekers and refugees - can be reduced to the same dimension (for the same finding with the 
Table 2 Categorical Principal Component Analysis - Two-dimensional solution

\begin{tabular}{|c|c|c|}
\hline Variables & Dimension IRO & Dimension CRI \\
\hline Labour entry & .79 & -.23 \\
\hline Labour stay & .80 & -.20 \\
\hline Family entry & .80 & .11 \\
\hline Family stay & .81 & .18 \\
\hline Asylum entry & .72 & -.07 \\
\hline Asylum stay & .76 & .10 \\
\hline Strength of jus soli & -.17 & .83 \\
\hline Residence duration requirement (reversed) & .05 & .84 \\
\hline Multiple citizenship toleration & .06 & .57 \\
\hline Further naturalisation requirements & -.02 & .65 \\
\hline Eigenvalue & 3.69 & 2.30 \\
\hline Explained variance & 36.86 & 22.97 \\
\hline Cronbach's alpha & .81 & .63 \\
\hline Model Eigenvalue & 5.98 & \\
\hline Model explained variance & 59.83 & \\
\hline Model Cronbach's alpha & .93 & \\
\hline
\end{tabular}

$N=713$ country-years; principal component analysis for categorical data (CATPCA) using selected policy components measuring the openness of immigration regimes according to IMPIC (Helbling et al. 2017) and the policy components of CITRIX (original dataset based on temporal expansion of selected items from MIPEX and based on the data by Stadlmair (2017) and Fitzgerald et al. (2014) and DEMIG and GLOBALCIT) measuring the inclusiveness of citizenship regimes variable principal normalisation; solution with VARIMAX rotation and Kaiser normalisation; entries are component loadings and model parameters; component loadings $>0.5$ bold

original components of IRO see Schmid and Helbling 2016). This supports the argument that economic and political liberalism are complementary rather than contradictory structural forces. The logic of the market and the legal logic of the liberal state appear to go together. Furthermore, this scrutiny suggests that democracies letting immigrants enter more easily have also tended to let them stay; these two aspects do not trade off (cf. Ruhs 2013).

Second, the existing literature points to possible multi-dimensionality also in the realm of citizenship regimes. On the one hand, the literature has diagnosed a liberalising tendency in citizenship policies concerning the reduction of residence duration requirements, the toleration of multiple citizenship, and the strengthening of jus soli, especially across Europe (Bauböck et al. 2006; Joppke 2010). Faced with the fact of immigration, European democracies have developed (or retained) relatively inclusive citizenship laws - unless this movement toward more inclusive conceptions of nationhood and its manifestation in greater political liberalism was successfully contained by antiimmigrant counter-reactions from the far-right (Howard 2009). On the other hand, however, there has been much talk of a 'restrictive turn' in citizenship regime trajectories across Europe (e.g. Joppke 2008). This literature tends to focus on the remaining component of citizenship regimes, conceptualised here as further naturalisation requirements: language and citizenship tests - subsumed under the rubric of "civic integration" - as well as, secondarily, economic and criminal record requirements. Civic integration requirements have been theorised as a separate dimension that is orthogonal to the restrictive-liberal continuum of citizenship policies as defined by other components such as the residence duration requirement (Goodman 2010, p. 757). 
Based on a much larger number of observations than is typically employed, the analysis presented here supports the alternative view that the most important policy components of citizenship regimes regarding ordinary immigration - residence duration requirements, multiple citizenship toleration, the strength of jus soli, as well as further naturalisation requirements (language tests, citizenship tests, and economic and criminal record conditions) - can be reduced to the same dimension of CRI. While the differentiation of civic integration as a separate dimension may be important in conceptual terms, and useful for specific analytical purposes, this analysis thus suggests that this aspect can also be incorporated into a one-dimensional statistical measure of citizenship regimes, more comprehensively understood. This supports the view that liberal-democratic concerns (or illiberal ones) and inclusive conceptions of nationhood (or exclusive ones) go together in structuring coherent citizenship regimes, though the various policy components cannot be neatly aligned with these two underpinning structures.

\section{Configurational analysis}

How do the observations configure in the two-dimensional space defined by IRO and CRI? Figure 2 presents the empirical distribution of all country-year combinations, both for the whole observation period (on the very right) as well as broken down by three geopolitical periods, which roughly correspond to the three decades from 1980 to 2010 . Overall, most cases have relatively open immigration regimes and inclusive citizenship regimes (Fig. 2; 30\% of observations). Regimes with this liberal cosmopolitan quality have become much more frequent over time. They were least frequent during the last decade of the Cold War (1980-1991), but in the most recent observation period (2002-2010) they make up almost half of all observations (46\%).

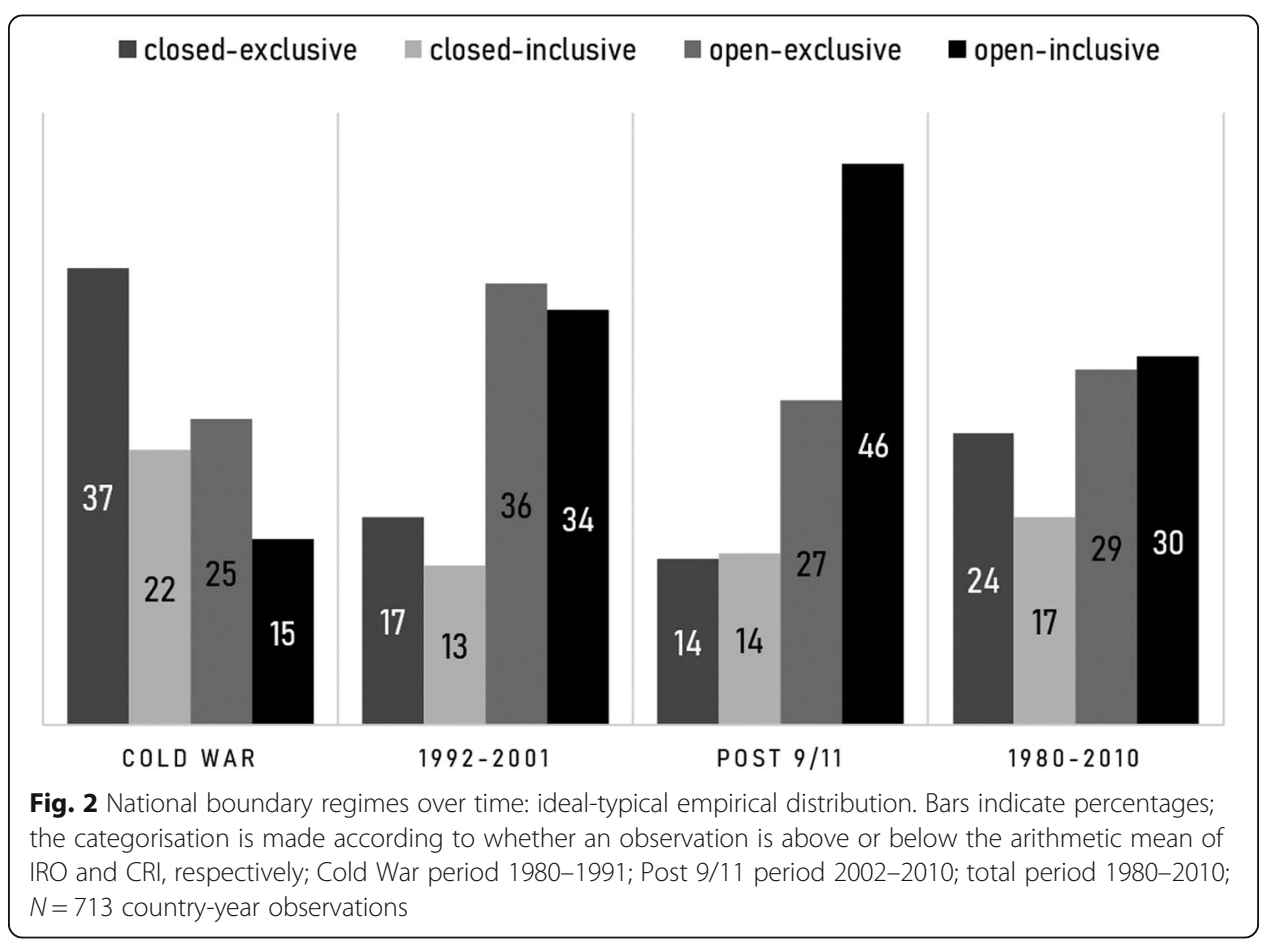


Closely following the open-inclusive cases, the second on the list are the openexclusive cases (29\%). They have reached a peak during the 1990s (36\%), while the decades before and after they make up about a fourth. As will be further demonstrated below, this has to do with the overall liberalising trajectory in citizenship policies, which led to a decrease in regimes akin to the 'Market Model' and to corresponding increase in regimes akin to the 'Liberal Model'. The number of observations that feature a closed immigration regime and an exclusive citizenship regime has dropped steadily by more than 20 percentage points from 1980 to 2010. During the Cold War they were very frequent (37\%), but then rapidly declined. Finally, it is striking that the classical model that dominates in the normative literature (closed immigration regime, inclusive citizenship regime) is clearly least prevalent empirically (17\%). Its highest share was also during the Cold War (22\%) - the decade in which this model found its classical formulation in Walzer (1983, ch. 2).

\section{Trend analysis}

How have immigration regimes and citizenship regimes evolved during recent decades? The previous analysis suggests that they have both liberalised. Fig. 3 shows this aggregate liberalising tendency in both IRO and CRI. ${ }^{3}$ However, after a surge of liberalisation from 1980 onwards, the trend toward more open immigration policies stops in 1996 and IRO fluctuates thereafter. Hence, the structural tendency of IRO towards greater openness - as a result of the constraints imposed by globalization - is limited. The trajectory of citizenship policies clearly shows the restrictive turn in the 2000s, which has been discussed in much of the literature (e.g. Joppke 2008). One can also detect another restrictive turn in citizenship during the 1990s. This is a novel finding. However, albeit limited, the aggregate tendency is toward greater CRI.

Regarding convergence, the declining trend in the standard deviation of IRO is particularly striking. It also continues after the aggregate level of IRO stagnates and fluctuates after 1996. The convergence in CRI is very limited (Fig. 3). Thus, whereas policy variation in immigration has decreased, variation in citizenship policies has not converged significantly. Indeed, citizenship policies have diverged somewhat during the time of its backsliding after 9/11. This indicates that the 'restrictive turn' in civic integration requirements has increased the variation across countries (Goodman 2014b).

These findings of liberalising trends and convergence in IRO but not CRI are in tune with the implications of my theoretical arguments. They also confirm previous analyses (e.g. Helbling and Kalkum 2018; Koopmans et al. 2012), while contradicting contrasting conjectures expecting greater liberalisation and convergence in CRI (e.g. Joppke 2010). However, the results also show important variation across geopolitical periods; the structural forces underpinning immigration and citizenship policies, their liberal and illiberal variants, and the interplay among them, appear to be dynamic.

\section{Correlation analysis}

Are immigration regimes and citizenship regimes statistically independent? The CATPCA has used an orthogonal VARIMAX rotation, which assumes a priori that the

${ }^{3}$ The evolution of policies by country is shown in Additional file 1. 


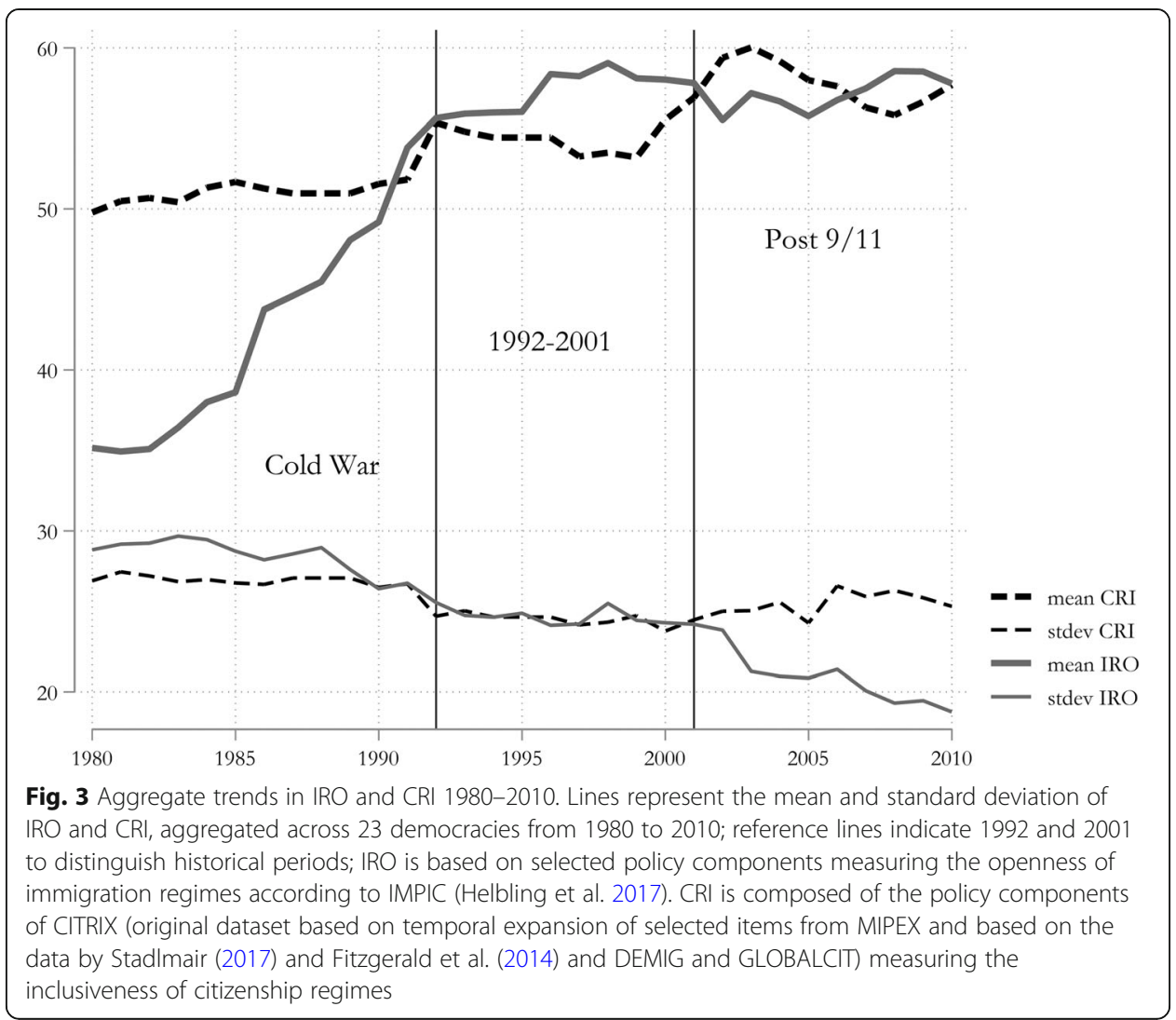

dimensions are uncorrelated. Solutions with non-orthogonal rotations show not only the same pattern of two-dimensionality, but also confirm that the correlation between IRO and CRI is low (PROMAX estimates a correlation of -0.07 ; OBLIMIN estimates a correlation of - 0.03). Using the IRO and CRI scales with (for IRO, transformed) arithmetic means is more adequate, because they are completely free of any assumptions and, in addition, are not dependent on variable parameters that go into the estimation of correlations between the dimensions when using PROMAX (I used the default Kappa $=4$ ) and OBLIMIN (I used the default Delta $=0$ ).

Table 3 shows that there is a conditional cross-case correlation between IRO and CRI: it increases over time. While there was virtually no correlation during the last decade of the Cold War, it increases to 0.18 during the 1990s, and to 0.36 after 9/11 (coefficients are Spearman's rho because of the ordinal nature of the data). The overall correlation is substantially low $(0.19)$ but has a very low p-value. Though there is only a

Table 3 How IRO-CRI cross-sectional correlations increase over time

\begin{tabular}{lllll}
\hline & \multicolumn{2}{l}{ Historical Period } & & \\
\cline { 2 - 3 } & Pooled & Cold War & $1992-2001$ & Post 9/11 \\
\hline rho & 0.19 & 0.08 & 0.18 & 0.38 \\
N-value & 0.000 & 0.164 & 0.007 & 0.000 \\
\hline & 713 & 276 & 230 & 207 \\
\hline
\end{tabular}

Entries are Spearman correlation coefficients and number of observations 
moderate correlation after $9 / 11$, this means that neither the widespread expectation of a negative correlation between IRO and CRI nor the alternative idea that the two policy areas are not systematically correlated receives empirical support. Instead, the increasingly positive correlation suggests that the logics driving immigration policies and citizenship policies have converged over time.

The correlation and its variation over time is visualised in Fig. 4 (thick dashed line). It also shows the variation in degree of all country-year observations. The movement of these dots over time gives us another angle on the configurational and trend analyses. From 1980 onwards, there is a movement to the right, which is accompanied by an increasing movement upwards. The latter inclusive move of the membership boundary becomes more significant over time (until the restrictive turn), whereas the opening move of the territorial boundary becomes less pronounced over time. Many countries become less closed-exclusive by becoming more open-exclusive, and then more openinclusive.

While the above configurational analysis shows what can be gained by a dichotomizing typological strategy, the full variation shown here should make us aware of what is hidden by this simplification. Note that, for instance - as can be expected from statistical measures - many observations cluster around the arithmetic means (indicated by the reference lines on both axes). This highlights the relativistic nature of the typology. Relatively open may not match the notion of openness as implied by some normative theory, and just because citizenship has become more inclusive does not necessarily mean that it is inclusive enough (or over-inclusive) when bearing a normative benchmark in mind (cf. Blatter et al. 2017).

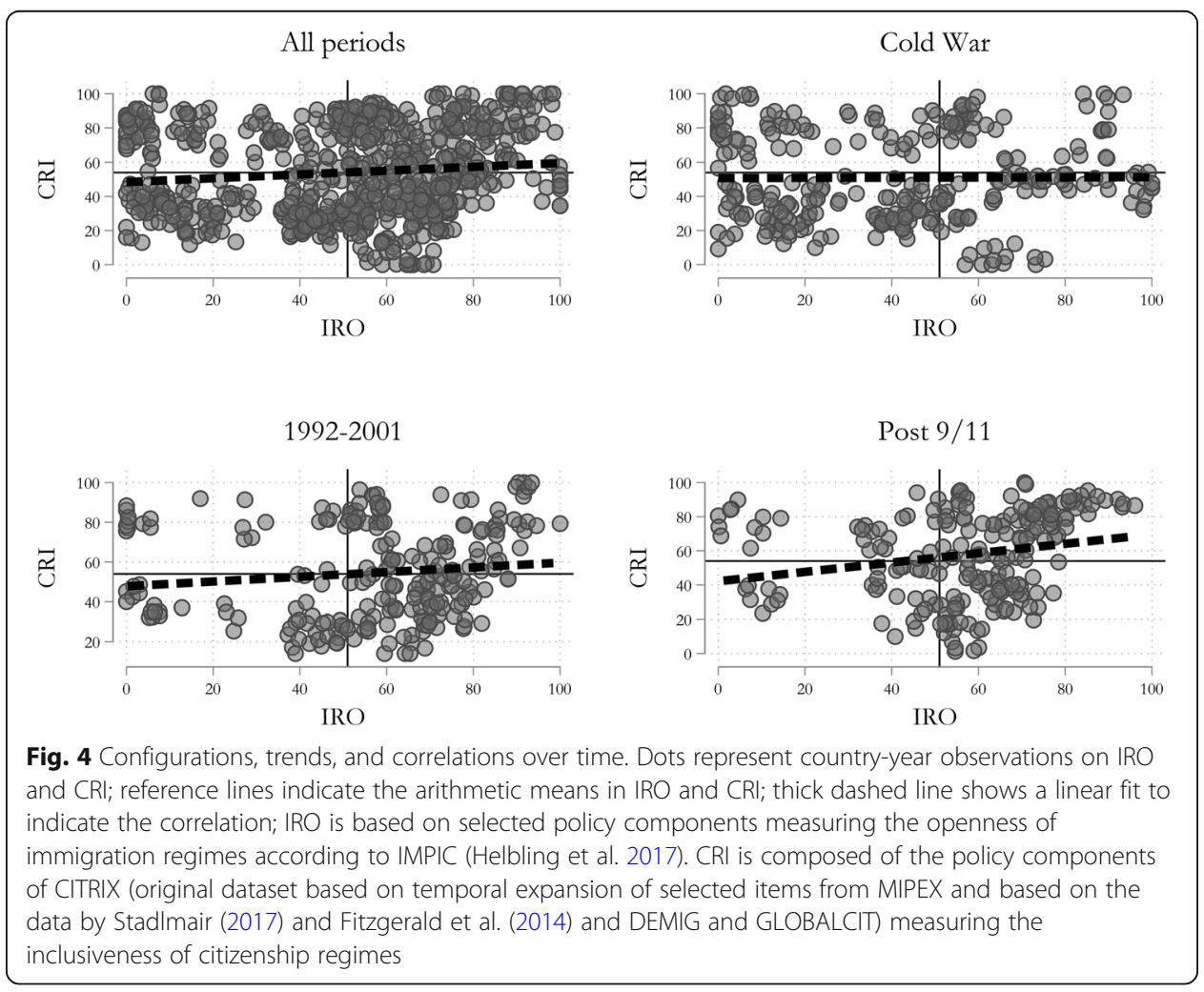




\section{Conclusion}

In this article, I have formulated a theory of the structural logics shaping immigration policies and citizenship policies - the logic of markets, the logic of nations, as well as the legal and the democratic logic of the liberal state (cf. Hampshire 2013). Based on this theory I have introduced a novel typology - called The National Boundary Regimes Typology - that focuses on the regulation of two fundamental social boundaries of modern nation-states: territorial boundaries (Immigration Regime Openness, IRO) and membership boundaries (Citizenship Regime Inclusiveness, CRI).

I have made four main empirical observations on the two-dimensional policy space determined by the different degrees of IRO and CRI, most of which are in accordance with the specified theoretical framework. First, a Categorical Principal Component Analysis (CATPCA) based on a combination of original and existing panel data across 23 liberal democracies from 1980 to 2010 has confirmed that IRO and CRI are internally consistent and statistically distinct dimensions. I have thereby provided empirical evidence for the existence of these dimensions - something which is lacking in the literature (Koopmans 2013, p. 696). The finding that there is no internal trade-off in immigration policies regarding different migrant groups suggests that economic liberalism - embodied in the economic logic of the market - and political liberalism - embodied in the legal logic of the liberal state are rather complementary than contradictory forces in determining the openness of immigration policies. Similarly, the finding that citizenship policies are coherent suggests that the interaction of the democratic logic of the liberal state with the cultural logic of the nation leads to a single empirical dimension of inclusiveness. Often seen as something different, civic integration requirements are part of this singular statistical continuum.

Second, the distribution of cases over the four ideal-typical policy configurations from 1980 to 2010 has shown that more and more cases combine relatively liberal immigration policies with relatively liberal citizenship policies; they are open-inclusive and thus have a liberal-cosmopolitan quality. This demonstrates that the 'liberal paradox' (Hollifield 1992, 2004) has been increasingly resolved, and the 'Liberal Model' rather than the 'Market Model' (Boucher and Gest 2018) has become more prevalent.

Third, the aggregate levels of both IRO and CRI follow overall liberalising trajectories with convergence in immigration and non-convergence in citizenship. However, the liberalisation in immigration policies stops in 1996 and fluctuates thereafter. This trend indicates that the constraints by globalization, which should lead to greater openness, are limited. The non-convergence in citizenship policies highlights national pathdependencies. This is confirmed by a disaggregated analysis showing the evolution of policies by country (see Additional file 1). The analysis has also shown a restrictive turn in citizenship policies during the 2000s, which is concurrent with expectations in the literature. The novel finding in this article is that another restrictive turn has already taken place during the 1990s. This suggests that also illiberal and exclusive forces have been at work in the realm of citizenship.

Fourth, this article has also shown that there is an increasingly positive correlation between IRO and CRI. This stands in contrast to the widespread assumption that there is a general trade-off or negative correlation between the territorial and membership dimensions of national boundary regimes (e.g. Ruhs 2013; Walzer 1983, ch. 2). This result suggests that the different structural logics do not remain distinct; they converge or coalesce over time. 
These four observations corroborate the theory proposed in this article. However, this theory needs to be both more rigorously tested and developed further. Indeed, the analytical framework has many more empirical implications, most of which will manifest only in qualitative data of specific cases. Besides looking for traces of the theorized structural logics and their interactions in case studies, the framework also must be subjected to tests using further statistical techniques - namely panel regressions of IRO on CRI, and vice-versa - to ascertain whether there is a correlation. In addition, this structuralist framework has to be complemented by an account of how politics unfolds within, employs, manipulates, and shapes the underlying logics. ${ }^{4}$ By arguing and illustrating empirically that these structural logics underpinning national boundary regimes create an architecture that is not set in stone but has evolved over time, in this article I have provided both a theoretical and empirical yardstick to address these questions.

\section{Supplementary information}

Supplementary information accompanies this paper at https://doi.org/10.1186/s40878-020-00182-5 .

\section{Additional file 1.}

\section{Acknowledgements}

There are many who deserve my gratitude for helping me craft and improve this article. Here I will mention only two key people. My supervisor Rainer Bauböck and my co-supervisor Maarten Vink have masterfully guided me in transforming the first timid version of this paper into a self-confident article. Their professional dedication, tireless support, and generous encouragement have left me truly amazed and deeply thankful. All remaining errors are mine.

\section{Author's contributions}

The author(s) read and approved the final manuscript.

\section{Author's information}

Samuel D. Schmid is a doctoral researcher at the European University Institute (IT) and a doctoral fellow at the Max Planck Institute for the Study of Religious and Ethnic Diversity (DE).

\section{Funding}

This research has been supported by three institutions. The State Secretariat for Education, Research and Innovation of the Swiss Confederation has granted a scholarship for doctoral research at the European University Institute in Florence, Italy. The Max Planck Institute for the Study of Religious and Ethnic Diversity in Göttingen, Germany, has provided funding as well as various institutional resources. The funding bodies had no role in the design of the study and collection, analysis, and interpretation of data and in writing this article.

\section{Availability of data and materials}

The datasets and the replication code for the stastitical analyses will be posted upon publication online at https://doi. org/10.7910/DVN/OAY6P7

\section{Competing interests}

The author declared no potential conflicts of interest with respect to the research, authorship, and/or publication of this article.

Received: 16 October 2019 Accepted: 6 May 2020

Published online: 20 July 2020

\section{References}

Bauböck, R., et al. (2006). Acquisition and loss of nationality. Amsterdam: Amsterdam University Press.

Bauböck, R., et al. (2013). Access to citizenship and its impact on immigrant integration. Florence: European University Institute. Bearce, D., \& Hart, A. (2018). Labour migration numbers and rights. In International Interactions online first. 15(1), 28-53. Beine, M., et al. (2016). Comparing immigration policies. International Migration Review, 50(4), 827-863.

Bjerre, L. Helbling, M., Römer, F., \& Zobel, M. (2016). The immigration policies in comparison (IMPIC) dataset. WZB Discussion Paper, SP VI 2016-201.

Blatter, J., Schmid, S.D., Blättler, A.C. (2017). Democratic deficits in Europe. Journal of Common Market Studies, 55(3), $449-467$.

${ }^{4}$ For a unique example of such a theory and supporting empirical analysis showing a strong positive correlation of immigration openness and immigrant rights in labor migration policies see Bearce and Hart (2018). 
Bosniak, L. (2006). The citizen and the alien. Princeton: Princeton University Press.

Boucher, A., \& Gest, J. (2015). Migration studies at a crossroads. Migration Studies, 3(2), 182-198.

Boucher, A., \& Gest, J. (2018). Crossroads. Cambridge: Cambridge University Press.

Brubaker, R. (1992). Citizenship and nationhood in France and Germany. Cambridge: Harvard University Press.

Carens, J. (2013). The ethics of immigration. New York: Oxford University Press.

Cornelius, W., et al. (2014). Controlling immigration. Stanford: Stanford University Press.

Dauvergne, C. (2004). Sovereignty, migration and the rule of law in global times. Modern Law Review, 67(4), 588-615.

de Haas, H., Natter, K., \& Vezzoli, S. (2015). Conceptualizing and measuring migration policy change. Comparative Migration

Studies, 3(15), 1-21.

de Haas, H., Natter, K., \& Vezzoli, S. (2016). Growing restrictiveness or changing selection? International Migration Review, 52(2), 324-367.

Džankić, J. (2019). The global market for investor citizenship. Cham: Palgrave Macmillan.

Fitzgerald, J., Leblang, D., \& Teets, J. (2014). Defying the law of gravity. World Politics, 66(3), 406-445.

Freeman, G. (1995). Modes of immigration politics in Liberal democratic states. International Migration Review, 29(4), 881-902.

Goodman, S. (2010). Integration requirements for integration's sake? Journal of Ethnic and Migration Studies, 36(5), 753-772.

Goodman, S. (2014a). Immigration and integration policies in Europe. In J. Magone (Ed.), Routledge handbook of European

politics. Hoboken: Taylor and Francis.

Goodman, S. (2014b). Immigration and membership politics in Western Europe. New York: Cambridge University Press.

Hammar, T. (1985). European immigration policy. Cambridge: Cambridge University Press.

Hammar, T. (1990). Democracy and the nation state. Aldershot: Ashgate.

Hampshire, J. (2013). The politics of immigration. Cambridge: Polity Press.

Helbling, M., \& Kalkum, D. (2018). Migration policy trends in OECD countries. Journal of European Public Policy, 25(12), 1779-1797.

Helbling, M., et al. (2017). Measuring immigration policies: The IMPIC database. European Political Science, 16(1), 79-98.

Hollifield, J. (1992). Immigrants, markets, and states. Cambridge: Harvard University Press.

Hollifield, J. (2004). The emerging migration state. International Migration Review, 38(3), 885-912.

Hollifield, J., \& Faruk, R. (2017). Governing migration in an age of globalization. In G. Carolus et al. (Eds.), Migration on the move (pp. 118-145). Leiden: Brill.

Howard, M. (2009). The politics of citizenship in Europe. New York: Cambridge University Press.

Huddleston, T., \& Niessen, J. (2011). Migrant integration policy index. Brussels: British Council and Migration Policy Group.

Huddleston, T., \& Vink, M. (2015). Full membership or equal rights? Comparative Migration Studies, 3(8), 1-19.

Jolliffe, I. (2002). Principal component analysis. New York: Springer.

Joppke, C. (1998). Why Liberal states accept unwanted immigration. World Politics, 50(2), 266-293.

Joppke, C. (2001). The legal-domestic sources of immigrant rights. Comparative Political Studies, 34(4), 339-366.

Joppke, C. (2008). Comparative citizenship. Law \& Ethics of Human Rights, 2(1), 1-41.

Joppke, C. (2010). Citizenship and immigration. Cambridge: Polity Press.

Koopmans, R. (2013). Indices of immigrant rights. Comparative European Politics, 11(5), 696-703.

Koopmans, R., Michalowski, I., \& Waibel, S. (2012). Citizenship rights for immigrants. American Journal of Sociology, 117(4), 1202-1245.

Koopmans, R., et al. (2005). Contested citizenship. Minneapolis: University of Minnesota Press.

Linting, M., et al. (2007). Nonlinear principal components analysis. Psychological Methods, 12(3), 336-358.

Lutz, P. (2019). Reassessing the gap-hypothesis. In Party Politics online first.

Meulman, J., \& Heiser, W. (2005). Categories 14.0. Chicago: SPSS.

Neumayer, E. (2005). Bogus Refugees? International Studies Quarterly, 49(3), 389-410.

Peters, M. (2017). Trading Barriers. Princeton: Princeton University Press.

Ruhs, M. (2013). The Price of rights. Princeton: Princeton University Press.

Sassen, S. (1996). Beyond sovereignty. Social Justice, 23(3), 9-20.

Schmid, S.D., \& Helbling, M. (2016). Validating the Immigration Policies in Comparison (IMPIC) Dataset. WZB Social Science

Center, Berlin: WZB Discussion Paper SP VI 2016-202.

Schmid, S.D., Piccoli, L., Arrighi, J.-T. (2019). Non-universal suffrage. European Political Science, 18, 695-713.

Shachar, A. (2018). The marketization of citizenship in an age of restrictionism. Ethics \& International Affairs, 32(1), 3-13.

Spiro, P. (2011). A new international law of citizenship. American Journal of International Law, 105, 694.

Stadlmair, J. (2017). Which policies matter? Österreichische Zeitschrift für Politikwissenschaft, 46(1), 60-73.

Vink, M. (2017). Comparing citizenship regimes. In A. Shachar, R. Bauböck, I. Bloemraad, \& M. Vink (Eds.), The Oxford handbook of citizenship (pp. 221-245). Oxford: Oxford University Press.

Vink, M., \& Bauböck, R. (2013). Citizenship configurations. Comparative European Politics, 11(5), 621-648.

Walzer, M. (1983). Spheres of justice. New York: Basic Books.

Weber, M. (1946). From max Weber: Essays in sociology. New York: Oxford University Press.

\section{Publisher's Note}

Springer Nature remains neutral with regard to jurisdictional claims in published maps and institutional affiliations. 